\title{
ADENOVIRUS-MEDIATED GENETIC MANIPULATION OF THE MYOCARDIAL B-ADRENERGIC SIGNALING SYSTEM IN TRANSPLANTED HEARTS
}

Ashish S. Shah, MD

David C. White, MD

Oliver Tai, BS ${ }^{\mathrm{a}}$

Jonathan A. Hata, BA ${ }^{\mathrm{a}}$

Katrina H. Wilson, BS ${ }^{\text {b,c }}$

Anne Pippen, BS ${ }^{\mathrm{b}}$

Alan P. Kypson, MD

Donald D. Glower, MD

Robert J. Lefkowitz, MD ${ }^{\text {b,c }}$

Walter J. Koch, $\mathrm{PhD}^{\mathrm{a}}$
Objectives: Ex vivo perfusion of the cardiac allograft during organ procurement is an ideal environment for adenoviral vectors with transgenes that target improving graft contractility. One such target is the $\beta$-adrenergic receptor-signaling system, in which alterations in transgenic mice have elucidated novel means to improve the function of the heart in vivo. The purpose of the current study was to determine the functional consequences of $\beta$-adrenergic receptor manipulation in a rabbit model of cardiac allograft transplantation.

Methods: New Zealand White rabbits weighing $3 \mathrm{~kg}$ served as recipients to $1-\mathrm{kg}$ outbred donors. Donor hearts were arrested and harvested, and 1 of 3 adenoviral constructs was administered into the aortic root perfusing the graft. Transgenes delivered encoded either the human $\beta_{2}$-adrenergic receptor, a peptide inhibitor of $\beta$-adrenergic receptor densensitization, or the marker transgene $\beta$-galactosidase.

Results: Five days after cervical heterotopic transplantation, left ventricular performance was measured on a Langendorff apparatus. A moderate pattern of rejection was seen in all grafts. Biventricular myocyte expression of $\beta$-galactosidase was observed, and $\beta_{2}$-adrenergic receptor density was elevated 10 -fold in grafts that received adeno- $\beta_{2}$-adrenergic receptor. Left ventricular systolic and diastolic performance was significantly increased in grafts transfected with either adeno- $\beta_{2}$-adrenergic receptor or adeno- $\beta$ adrenergic receptor densensitization compared with control grafts that received adeno- $\beta$-galactosidase.

Conclusions: Ex vivo adenovirus-mediated gene transfer is feasible in a rabbit allograft model and, more important, genetic manipulation of $\beta$-adrenergic receptor signaling either by increasing $\beta_{2}$-adrenergic receptor density or blocking endogenous receptor desensitization improves graft function acutely in this allograft model. (J Thorac Cardiovasc Surg 2000;120:581-8)
V entricular dysfunction after heart transplantation is an attractive target for cardiac gene therapy. There are multiple causes of graft dysfunction, including preservation injury, rejection, and pulmonary hypertension. ${ }^{1}$ Current therapeutic approaches center on pharmacologic and mechanical support that historically have been associated with poor outcomes in the periop-

From the Departments of General and Thoracic Surgery ${ }^{\mathrm{a}}$ and Medicine $^{\mathrm{b}}$ and the Howard Hughes Medical Institute, ${ }^{c}$ Duke University Medical Center, Durham, NC.

This work was supported by National Institute of Health grants HL59533 and HL-56205 to W.J.K. R.J.L. is an investigator of the Howard Hughes Medical Institute.

Received for publication Jan 20, 2000; revisions requested Feb 28, 2000; revisions received March 20, 2000; accepted for publication March 27, 2000. erative period. ${ }^{2}$ However, recent innovations in therapies have had a positive effect. Nonetheless, a molecular strategy may provide an important form of ventricular support in the setting of acute graft dysfunction.

$\beta$-Adrenergic receptor ( $\beta$-AR) signaling abnormalities have been well described in native heart failure ${ }^{3,4}$; however, $\beta$-AR signaling in transplanted myocardium

\footnotetext{
Address for reprints: Walter J. Koch, PhD, Box 2606, MSRB Room 471, Duke University Medical Center, Durham, NC 27710 (Email:koch0002@mc.duke.edu).

Copyright (C) 2000 by The American Association for Thoracic Surgery

$0022-5223 / 2000 \$ 12.00+0 \quad \mathbf{1 2 / 1 / 1 0 7 5 1 9}$
}

doi:10.1067/mtc.2000.107519 
has not been clearly understood to date. Evidence exists for upregulation of $\beta_{2}$-ARs, whereas $\beta_{1}$-ARs downregulate, and receptors are uncoupled in grafts undergoing acute rejection. ${ }^{5-8}$ Therefore, transplanted myocardium appears to recapitulate, at least in part, the $\beta$-AR signaling abnormalities associated with heart failure, despite its unique physiology. Accordingly, a therapeutic strategy to enhance $\beta$-AR signaling may provide an intrinsic form of ventricular support for the grafted heart. This approach includes enhancement of $\beta$-AR signaling through overexpression of the $\beta_{2}$-AR or inhibiting desensitization. To inhibit $\beta$-AR desensitization, our laboratory has developed and used an inhibitor of $\beta$-adrenergic receptor kinase 1 ( $\beta$-ARK1), the $\beta$ ARKct, which is a 194-amino acid peptide that competes with $\beta$-ARK1 for binding to the $\beta \gamma$-subunit of activated heterotrimeric $\mathrm{G}$ proteins $\left(\mathrm{G}_{\beta \gamma}\right)$, a process required for $\beta$-ARK1 activation. ${ }^{9,10}$ Interestingly, in transgenic mice myocardium-targeted overexpression of $\beta_{2}$-ARs at greater than 100 -fold over endogenous levels ${ }^{11}$ or the $\beta$-ARKct ${ }^{10}$ resulted in significantly enhanced in vivo cardiac function without significant pathology, ${ }^{12}$ whereas 10 -fold overexpression of the $\beta_{1^{-}}$ $\mathrm{AR}$ in the hearts of transgenic mice leads to early hypertrophy and cardiomyopathy. ${ }^{13}$ Thus, the $\beta_{2}$-AR appears to offer a therapeutic advantage over the $\beta_{1}$ AR. ${ }^{12}$ Furthermore, $\beta$-AR signaling abnormalities present in isolated failing cardiomyocytes have been rescued by adenovirus-mediated overexpression of the $\beta_{2}$-AR or the $\beta$-ARKct. ${ }^{14}$

Previous work in our laboratory and others has demonstrated the feasibility of transgene delivery by using adenoviral vectors to grafts during harvesting and implantation. ${ }^{15-18}$ Work by Brauner and colleagues ${ }^{19}$ and Qin and associates $^{20}$ has also demonstrated the possibility of immune modulation by using immunosuppressant transgenes, such as tumor growth factor $\beta$ and interleukin 10 . The focus of the current study was to examine the functional consequences of adenovirus-mediated gene transfer of transgenes that enhance $\beta$-AR signaling. Potentially, this could lead to improved cardiac allograft contractility that could favorably go hand in hand with genetic manipulation of immune properties of the graft to improve cardiac dysfunction seen perioperatively and during acute rejection episodes.

\section{Methods}

Adenoviral constructs. Adenoviral constructs with a firstgeneration, E1/E3-deleted, replication-deficient adenovirus have previously been described. The $\beta_{2}$-AR (adeno- $\beta_{2} \mathrm{AR}$ ), $\beta$ ARKct (adeno- $\beta$-ARKct), and marker transgene $\beta$-galactosidase (adeno- $\beta \mathrm{Gal}$ ) were driven by the cytomegalovirus promoter. Large-scale preparations of these adenoviruses were purified from transfected 293 cells, as previously described. ${ }^{14,15}$

Animal preparation. Male New Zealand White rabbits (3 $\mathrm{kg}$ ) served as recipients to $1-\mathrm{kg}$ donors and were obtained from separate vendors. All procedures were humanely performed in accordance with the regulations adopted by the National Institutes of Health and approved by the Animal Care and Use Committee of Duke University. Each animal was sedated with ketamine $(80 \mathrm{mg} / \mathrm{kg})$ and acepromazine maleate (INN: acepromazine; $0.25 \mathrm{mg} / \mathrm{kg}$ ). The recipient was then shaved and prepared in a sterile fashion over the right side of the neck, and an incision was made with $1 \%$ lidocaine. The internal carotid and external jugular veins were then dissected, and $500 \mathrm{U}$ of heparin was given to the recipient. Attention was then turned to the donor. After endotracheal intubation and ventilation, the heart was exposed by means of a clamshell incision. Three thousand units of heparin was then administered into the inferior vena cava, and it was ligated with 3-0 silk suture. The aorta and pulmonary artery were then dissected, and a clamp was placed across the aorta. Fifteen milliliters of University of Wisconsin solution was then delivered into the aortic root, and the great vessels were transected. The remaining vessels were ligated en bloc, and the heart was placed in saline solution at $4^{\circ} \mathrm{C}$. Total viral particles $\left(1 \times 10^{10}\right)$ in a total saline volume of $1.0 \mathrm{~mL}$ of a replication-deficient adenovirus containing adeno- $\beta$-ARKct $(\mathrm{n}=12)$, adeno- $\beta$-Gal $(\mathrm{n}=8)$, adeno- $\beta_{2}$-AR $(\mathrm{n}=10)$, or saline solution $(n=4)$ were then injected into the aortic root and through the coronary arteries. The graft was then anastamosed to the recipient vessels with 7-0 Prolene sutures (Ethicon, Inc, Somerville, NJ). The donor aorta was anastamosed end to side to the carotid artery, and the donor pulmonary artery was anastomosed to the jugular vein. ${ }^{19,21}$ Grafts were then reperfused and resumed vigorous contraction within 5 minutes. Total ischemic time was approximately 50 minutes for all grafts. All grafts were palpated daily.

Functional assessment. On postoperative day 5, grafts were excised and placed on a modified Langendorff apparatus for measurement of left ventricular (LV) function. ${ }^{16,22}$ A balloon was placed into the left ventricle through the left atrium, inflated to 8 to $10 \mathrm{~mm} \mathrm{Hg}$, and connected to a micromanometer to measure intracavitary pressure. The coronary perfusion flow was maintained at $20 \mathrm{~mL} / \mathrm{min}$ at $35^{\circ} \mathrm{C}$. Oxygenated modified Krebs-Henseleit solution was used as the perfusate. ${ }^{16}$ After 30 minutes of equilibration, LV intracavitary pressure was recorded on a personal computer-based acquisition system at $200 \mathrm{~Hz}$ (Physiologic Systems, Durham, NC) while being paced at 215 beats/min. After acquisition of baseline data, epinephrine $\left(10^{-7} \mathrm{~mol} / \mathrm{L}\right)$ was infused, and the maximal response was measured. After data acquisition, transmural samples of the left and right ventricles were then frozen in liquid nitrogen for biochemical analysis. The maximal rate of LV pressure rise $\left(\mathrm{dP} / \mathrm{dt}_{\max }\right)$ was used as a measure of contractile function and derived from the average of 20 steady-state beats. The minimum $\left(\mathrm{dP} / \mathrm{dt}_{\text {min }}\right)$ was used as a measure of global ventricular relaxation. 

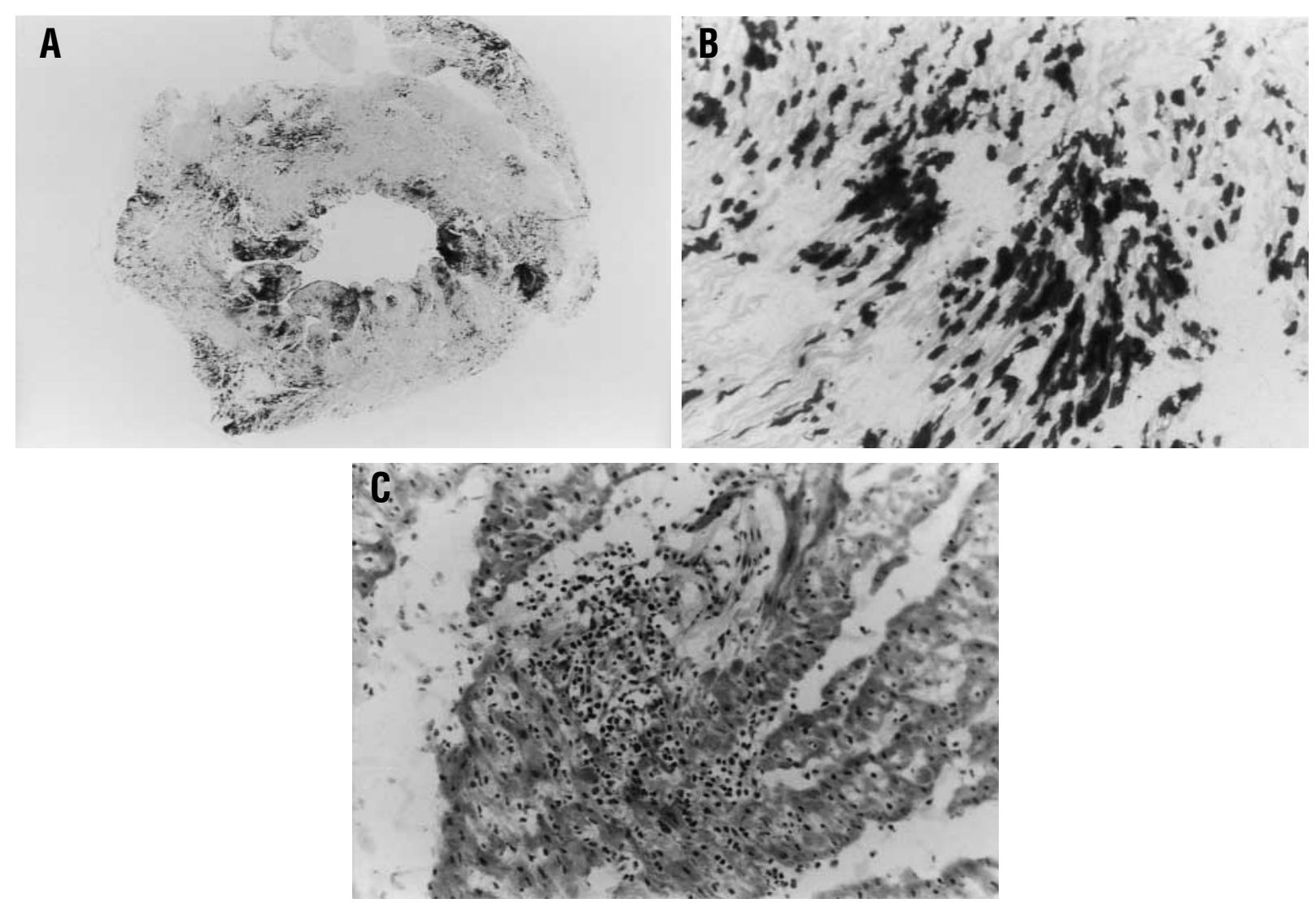

Fig 1. Representative histologic specimens of rabbit cardiac allografts treated with adeno- $\beta$-Gal. A, Whole mount (low-power) section of a heart 5 days after the ex vivo delivery of $1 \times 10^{10}$ total viral particles of adeno- $\beta$-Gal and heterotopic transplantation. Global and robust myocardial expression of $\beta$-Gal is evident. $\mathbf{B}$, A higher power view demonstrating that the $\beta$-Gal transgene is expressed in individual myocytes. $\mathbf{C}$, Hematoxylin and eosin-stained section from the right ventricle of a saline-treated allograft 5 days after transplantation with evidence of infiltrating inflammatory cells, indicating a moderate pattern of rejection in this transplanted heart.

Determination of myocardial $\beta$-AR density. $\beta$-AR binding was performed from purified myocardial sarcolemmal membranes, as previously described. ${ }^{10,11}$ Final membranes were resuspended at 1 to $2 \mathrm{mg} / \mathrm{mL}$, and total $\beta$-AR density was determined by incubating $25 \mu \mathrm{g}$ of sarcolemmal membranes with a saturating concentration $(300 \mathrm{pmol} / \mathrm{L})$ of $\left[{ }^{125} \mathrm{I}\right]$-cyanopindolol and $20 \mu \mathrm{mol} / \mathrm{L}$ alprenolol to define nonspecific binding. ${ }^{10,11}$

Protein immunoblotting. Protein immunoblotting to detect the presence of the $\beta$-ARKct was performed, as previously described, by using polyclonal antiserum raised to the carboxyl terminus of $\beta$-ARK $1 .{ }^{14}$ Immunodetection of myocardial levels of $\beta$-ARK1 was performed on equal amounts of protein from cytosolic extracts after immunoprecipitation by means of a monoclonal $\beta$-ARK1 antibody. ${ }^{14}$

Histologic and $\beta$-Gal staining. After excision, transverse cross sections of myocardium at the midpapillary level were obtained for histologic analysis and stored in 30\% sucrose solution before paraffin embedding, as previously described. ${ }^{15,16}$ Paraffin-embedded samples were mounted on a cryostat and sectioned into 5- to $10-\mu \mathrm{m}$ thin sections, which were then transferred to a glass slide. $\beta$-Gal staining was performed in $5 \mathrm{mmol} / \mathrm{L}$ ferrocyanide, $5 \mathrm{mmol} / \mathrm{L}$ ferriccyanide, 2 $\mathrm{mmol} / \mathrm{L} \mathrm{MgCl}_{2}, 0.02 \%$ Igepal CA-630 (Sigma Chemical Co, St Louis, Mo), $0.01 \%$ sodium deoxycholate, $5 \mathrm{mmol} / \mathrm{L}$ ethyleneglycol-bis-( $\beta$-aminoethylether)- $N, N, N^{\prime}, N^{\prime}$-tetraacetic acid, and $1 \mathrm{mg} / \mathrm{mL}$ X-Gal in Tris-buffered saline solution $(\mathrm{pH} 7.5)$ at $37^{\circ} \mathrm{C}$ for up to 24 hours. Hematoxylin and eosin staining was performed on all samples by using standard techniques. ${ }^{15,16}$

Data analysis. All summary data are expressed as the mean \pm SEM. All comparisons were performed by a 1-way analysis of variance. Pairwise comparisons were then made with a Bonferroni $t$ test.

\section{Results}

Adenovirus-mediated expression of transgenes. Ex vivo delivery of adenoviral constructs resulted in biventricular expression of the respective transgenes. In grafts perfused with adeno- $\beta$-Gal, global expression of 

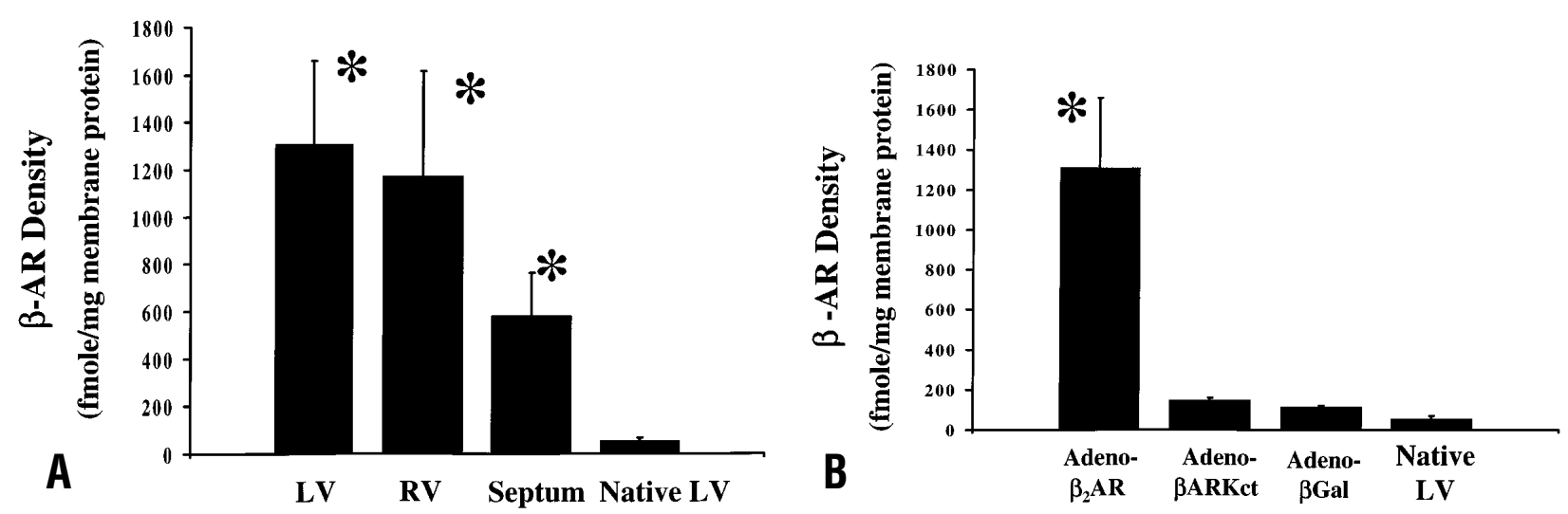

Fig 2. $\beta$-AR density in allografted hearts after ex vivo adenovirus-mediated gene delivery. A, Total $\beta$-AR density in grafts that received adeno- $\beta_{2}-\mathrm{AR}(\mathrm{n}=10)$. A 10 -fold overexpression was seen in grafts in both ventricles. ${ }^{*} P<.001$ versus native cardiac $\beta$-AR density. B, Total $\beta$-AR density in the left ventricle of all treated groups. Treatment of allografts with adeno- $\beta$-ARKct $(\mathrm{n}=12)$ or adeno- $\beta$-Gal $(\mathrm{n}=8)$ did not significantly alter myocardial $\beta$-AR density compared with native myocardium $(\mathrm{n}=6) .{ }^{*} P<.001$ versus adeno- $\beta$-ARKct, adeno- $\beta$-Gal, and native left ventricle. $L V$, Left ventricle; $R V$, right ventricle.

the transgene was seen throughout the myocardium (Fig 1, A). High-power views confirm the staining of individual myocytes and not inflammatory cells (Fig 1, $B)$. Importantly, donor and recipient animals were from different colonies, and thus a pattern of moderate rejection, as evidenced by inflammatory cell infiltrates, was seen in hearts 5 days after transplantation (Fig 1, C), making this an allograft model.

In grafts that received adeno- $\beta_{2}-\mathrm{AR}$, marked overexpression of the $\beta_{2}$-AR was observed throughout the myocardium, with over a 10 -fold increase in $\beta$-AR density compared with nontransplanted myocardium (Fig $2, A$ ). Significant overexpression of the $\beta_{2}$-AR was seen in the left ventricle, right ventricle, and septum, confirming an intracoronary delivery of adenoviral vectors previously illustrated above by the X-Gal staining. $\beta$ AR density was also performed on grafts that received adeno- $\beta$-ARKct and adeno- $\beta$-Gal. No significant alteration of $\beta$-AR density was observed in adeno- $\beta$ ARKct- and adeno- $\beta$-Gal-transfected grafts versus normal myocardium (Fig 2, B). This importantly demonstrates that donor hearts from nonisogenic strains do not have endogenously higher $\beta$-AR density, and the increased density seen in the adeno- $\beta_{2}-$ AR-treated grafts is caused by transgene expression. In addition, expression of adenoviral transgenes was not found in any organ or tissue of the recipient animal outside of the donor heart (data not shown). Protein immunoblotting was performed to detect the presence of the $\beta$-ARKct peptide. The presence of this peptide inhibitor of $\beta$-ARK1 activity was seen globally in grafts that received adeno- $\beta$-ARKct (Fig 3), but the 30$\mathrm{kd} \beta$-ARKct was not detected in the recipient's native myocardium (data not shown) or liver.

Functional consequence of transgene expression on $\mathrm{LV}$ contractile performance. The functional consequence of graft-specific $\beta$-AR transgene expression was evaluated on an isolated Langendorff apparatus. The maximal first derivative of intracavitary pressure $\left(\mathrm{dP} / \mathrm{dt}_{\max }\right)$ was used as a measure of global LV contractile performance 5 days after transgene delivery. Grafts that received either adeno- $\beta_{2}$-AR or adeno- $\beta$-ARKct had a significant improvement in systolic ventricular function compared with adeno- $\beta-G a l$ control grafts (Fig 4). The significant improvement in baseline function was similar in the hearts that received the 2 functional transgenes with increases of $129 \%$ and $123 \%$, respectively, from adeno- $\beta$-Gal-treated hearts (Fig 4, $A ; P<.05)$. Epinephrine was used to further characterize LV contractile function after transgene delivery. The $\mathrm{LV} \mathrm{dP/dt} t_{\text {max }}$ response to epinephrine was markedly increased in adeno- $\beta_{2}$-AR and adeno- $\beta$-ARKct grafts compared with adeno- $\beta$-Gal-treated hearts (Fig $4, B)$. Interestingly, hearts expressing $\beta$-ARKct had a greater increase in LV systolic performance in response to epinephrine compared with the increase found in $\beta_{2}$ AR-overexpressing transplanted hearts (Fig 4, B). We chose to measure function at 5 days after gene delivery because of our previous study in transplanted rat heart isografts that demonstrated that peak transgene expression was between 5 to 7 days, and by day 14, most of the transgene expression was absent, which is typical 


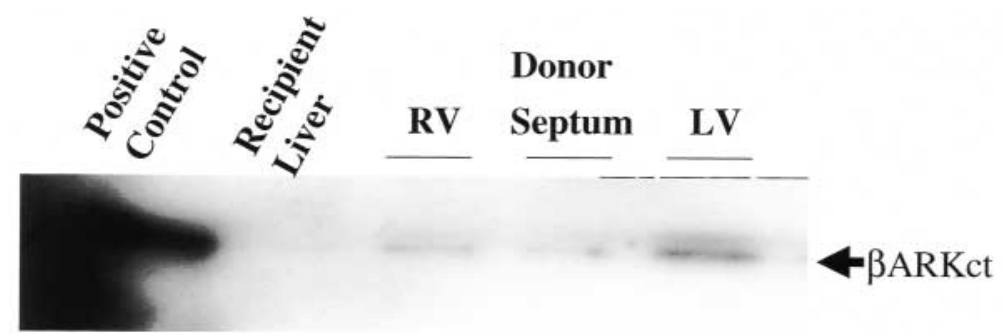

Fig 3. $\beta$-ARKct expression in allografted hearts after ex vivo adeno- $\beta$-ARKct delivery. Representative protein immunoblot of an allograft treated with adeno- $\beta$-ARKct. Presence of the approximately $30-\mathrm{kd}$ protein $\beta$-ARKct was confirmed in both chambers of the heart and absent in the recipient's liver. In addition, there was no detectable $\beta$-ARKct expression in the recipient's heart (data not shown). $R V$, Right ventricle; $L V$, left ventricle.
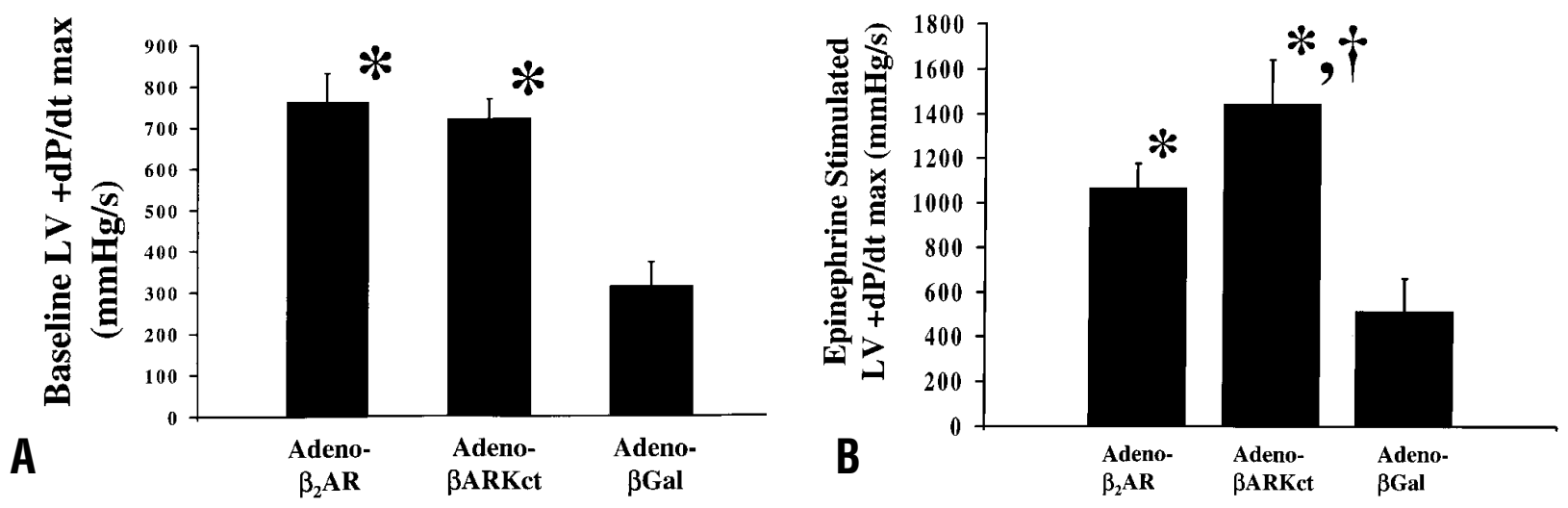

Fig 4. $\mathrm{LV} \mathrm{dP/dt} \mathrm{max}_{\text {max }}$, as a measure of cardiac contractile function, assessed on isolated allografts 5 days after gene delivery and heterotopic transplantation. $\mathbf{A}, \mathrm{dP} / \mathrm{dt}_{\max }$ was significantly increased at baseline in grafts treated with adeno- $\beta_{2}$-AR $(\mathrm{n}=10)$ or adeno- $\beta$-ARKct $(\mathrm{n}=12)$ compared with values in adeno- $\beta$-Gal-treated grafts $(\mathrm{n}=8) .{ }^{*} P$ $<.001$. B, $\mathrm{LV} \mathrm{dP} / \mathrm{dt}_{\max }$ responses to epinephrine $\left(10^{-7} \mathrm{~mol} / \mathrm{L}\right)$. Adeno- $\beta_{2}-\mathrm{AR}$ - and adeno- $\beta$-ARKct-treated grafts exhibited significant improvement in systolic function over adeno- $\beta$-Gal-treated hearts, and adeno- $\beta$-ARKcttreated hearts had a greater response to epinephrine compared with adeno- $\beta_{2}$-AR treatment. ${ }^{*} P=.006$ versus adeno- $\beta$-Gal. ${ }^{\dagger} P=.04$ versus adeno- $\beta_{2}$-AR.

of these types of adenovirus vectors. ${ }^{16}$ However, we did not measure the duration of transgene expression in this rabbit allograft model.

Using LV dP/dt $t_{\text {min }}$ as a measure of cardiac relaxation, a significant improvement in lusitropy was seen in adeno- $\beta$-ARKct- and adeno- $\beta_{2}-\mathrm{AR}$-transfected grafts compared with the diastolic function seen in control allografts that received adeno- $\beta$-Gal. No significant difference in relaxation was observed between adeno$\beta$-ARKct or adeno- $\beta_{2}$-AR grafts (Fig 5, $A$ ). Furthermore, ephinephrine-stimulated relaxation was significantly improved in grafts that received either of the 2 functional transgenes compared with adeno- $\beta$ Gal-treated control grafts (Fig 5, B). Importantly, $\beta$ ARKct and $\beta_{2}$-AR overexpression resulted in a similar enhancement of agonist-mediated $\mathrm{dP} / \mathrm{dt}_{\text {min }}$ responses.

\section{Discussion}

The major findings of the present study are 2-fold. First, this study expands the application of acquired transgenesis to the field of cardiac allograft transplantation and provides novel therapeutic targets to improve the functional performance of the donor heart. Previous reports in this area have concentrated on immunomodulation. ${ }^{19,20}$ Specifically, this study is unique in that it uses a rabbit allograft heterotopic heart transplant model to demonstrate that enhanced $\beta$-AR signaling, either through increased receptor density or inhibiting desensitization, leads to enhanced function of the graft, even in the face of mild-to-moderate rejection and ischemic injury. A second novel aspect of this study is that it represents the first report, outside transgenic mice, demonstrating that the $\beta$-ARKct and subsequent 


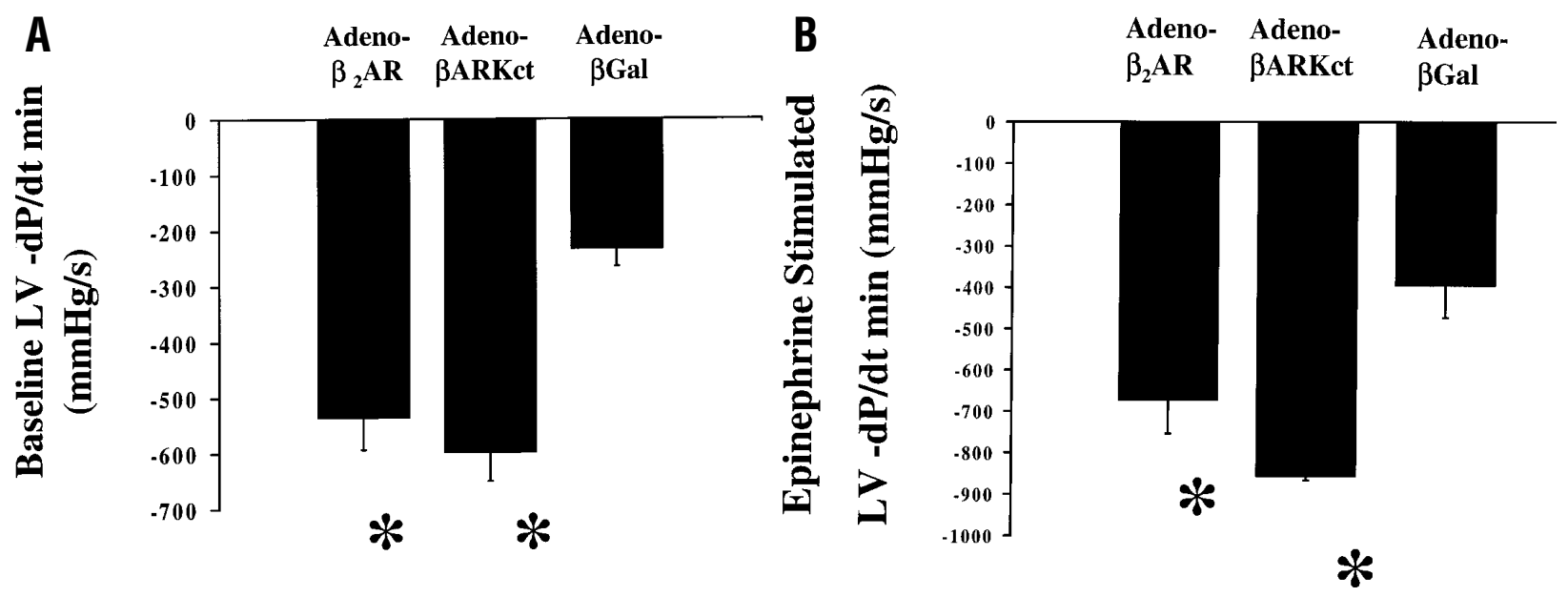

Fig 5. $\mathrm{LV} \mathrm{dP/dt} t_{\min }$, as a measure of cardiac relaxation assessed on isolated allografts 5 days after gene delivery and heterotopic transplantation. A, Both adeno- $\beta$-ARKct-transfected $(n=12)$ and adeno- $\beta_{2}-A R-$ transfected $(n=10)$ grafts showed marked improvement in baseline relaxation compared with adeno- $\beta$-Gal-treated control grafts $(\mathrm{n}=8)$. No significant difference in $\mathrm{dP} / \mathrm{dt}_{\text {min }}$ was observed between adeno- $\beta$-ARKct and adeno- $\beta_{2}-\mathrm{AR}$. B, Epinephrine $\left(10^{-7} \mathrm{~mol} / \mathrm{L}\right)$ stimulated relaxation. $\mathrm{LV} \mathrm{dP} / \mathrm{dt}_{\min }$ response was significantly greater in adeno- $\beta_{2}-\mathrm{AR}-$ and adeno- $\beta$-ARKct-treated animals compared with adeno- $\beta$-Gal treatment. ${ }^{*} P<.001$ versus adeno- $\beta$-Gal for both adeno- $\beta$-ARKct and adeno- $\beta_{2}$-AR.

inhibition of myocardial $\beta$-ARK1 activity leads to enhanced global cardiac contractility and relaxation. More important, this has taken place acutely after adenovirus-mediated gene delivery in a larger animal model that differs considerably from constitutive overexpression in transgenic mice.

The perioperative period after cardiac transplantation is a particularly tenuous time. Ischemia, as well as autonomic dysfunction in the brain-dead donor, can also affect ventricular function, probably as a result of $\beta$-AR desensitization. ${ }^{23,24}$ After graft implantation, the right ventricle is subjected to elevated afterload and may fail, causing further hemodynamic instability. These physiologic factors are further complicated by the fact that the transplanted heart is denervated and catecholamine dependent. All of these diverse variables affect and impinge on overall graft function, particularly in the perioperative period, and ultimately affect patient outcome. Thus, preserving the functional integrity of the grafted heart is an important goal that could also expand the use of marginal grafts that may be rescued with gene therapy.

Thirty years of research in preservation solutions has illustrated that metabolic manipulation of the graft during procurement is feasible. Recent work by our group and others has extended this concept to genetic manipulation. The cold, arrested, ischemic heart is an ideal milieu for gene transfer. First, ex vivo perfusion allows graft-limited contact with adenoviral vectors. Second, the transport and preservation time allows for sustained contact time and robust overexpression of transgenes at much lower viral titers than is needed for in vivo transfection. Thus in this rabbit allograft model we can directly test whether genetic manipulation of the myocardial $\beta$-AR system can lead to improved function perioperatively.

Overexpression of either $\beta_{2}$-ARs or blocking $\beta$ ARK1 in transgenic mouse models, studies in isolated cardiomyocytes, or both has been shown to reverse the changes seen in heart failure, as well as improving contractility in normal myocardium. ${ }^{10,11,14,25}$ These studies done in our laboratory form the basis of our current gene therapy strategy in transplanted myocardium. The present study is unique in that it uses a rejecting model of myocardium and attempts to improve function in this setting of graft dysfunction. Not only does this model incorporate immunologic injury, but there are elements of ischemic, as well as preservation and reperfusion, injury. Although none of these factors were individually identified, they all conspire in the early graft period, even in experimental transplantation. Of these factors, only ventricular loading is not present in commonly used heterotopic transplant models.

Part of the utility of $\beta$-AR manipulation in cardiac transplantation rests in the fact that signaling is altered in the perioperative period. It is increasingly clear that 
$\beta$-ARK1 is a critical regulator of myocardial function. Increased myocardial expression of $\beta$-ARK1 has been found to be associated with ventricular dysfunction in myocardial hypertrophy, ${ }^{26}$ ischemia, ${ }^{27}$ and human congestive heart failure. ${ }^{28}$ In addition, $\beta$-ARK1 upregulation has been implicated in human hypertension. ${ }^{29}$ Transgenic mice with increased $\beta$-ARK1 expression targeted to the heart were found to have $\beta$-AR receptor uncoupling and ventricular dysfunction after $\beta$-agonist administration. ${ }^{10}$ Actual uncoupling from second messenger systems in cardiac allografts, however, has been difficult to prove. Experimental evidence exists for a decline in adenylyl cyclase activity, ${ }^{7}$ but no clinical data exist in human transplantation. ${ }^{5}$ In several studies acute rejection was associated with a downregulation of total $\beta$-AR density, recapitulating changes seen in heart failure. ${ }^{3,8,30}$ Interestingly, we have found that $\beta$ ARK1 expression was elevated in our rabbit allografts (data not shown), and thus $\beta$-ARK1 upregulation may be responsible for some of the observed signaling abnormalities seen in both experimental and clinically transplanted hearts.

The current study demonstrates that adenovirusmediated delivery of transgenes to the transplanted heart is feasible through ex vivo perfusion and can improve contractile function. First, overexpression of $\beta_{2}$-ARs significantly improved contractile function 5 days after transplantation in this model both basally and in response to a $\beta$-agonist. Previous studies in transgenic mice have demonstrated that $\beta_{2}$-AR overexpression improves contractile function through improved coupling to second messenger systems and cyclic adenosine monophosphate production. ${ }^{11}$ Furthermore, acquired overexpression of $\beta_{2}$-ARs, either by ex vivo or in vivo adenovirus-mediated gene delivery to rat and rabbit hearts, has been found to improve normal and isografted myocardium. ${ }^{14,31}$ Because our rabbit model of transplantation involves a level of rejection, data from this study importantly provide evidence that $\beta_{2}$-AR overexpression can improve systolic and diastolic performance in the dysfunctional myocardium.

In this study the ex vivo delivery and expression of $\beta$ ARKct in grafts improved baseline LV contractile performance to the same extent as $\beta_{2}$-AR overexpression. Interestingly, although both transgenes were able to improve baseline systolic and diastolic performance, adeno- $\beta$-ARKct-treated cardiac allografts also exhibited a significant increase in inotropic response to a $\beta$ agonist over the improvement seen with $\beta_{2}$-AR overexpression. This improved $\beta$-AR responsiveness after $\beta$-ARKct expression may indicate that enhanced sig- naling through endogenous $\beta$-ARs (primarily $\beta_{1}$-ARs) is a more powerful means to improve the performance of the heart than overexpressing the $\beta_{2}$-AR. Thus $\beta$ ARK1 inhibition with the $\beta$-ARKct might be advantageous over $\beta_{2}$-AR overexpression. This may have profound implications and utility in transplantation. The transplanted heart is catecholamine dependent because it is denervated and, as such, safely improving inotropic responsiveness may further enhance in vivo function where circulating catecholamines play a role in baseline function. This study is among the first to compare the functional consequences of these 2 transgenes in a model of acquired transgenesis.

In summary, the results of this study demonstrate that altering $\beta$-AR signaling is an appealing target for cardiac gene therapy and provides a novel treatment strategy for ventricular dysfunction. Gene therapy to improve cardiac function in the setting of transplantation may provide substantial clinical benefit. The current study examined the functional consequences of 2 transgenes that alter $\beta$-AR signaling in different ways. They both significantly increased contractility in this model of cardiac allotransplantation. Future work will concentrate on using these powerful transgenes in larger loaded models of cardiac transplantation.

We thank Kyle Shotwell and Kurt Campbell for their excellent technical assistant and the Genzyme Corporation (Framingham, Mass) for preparation and purification of some of the adeno- $\beta_{2}$-AR and adeno- $\beta$-ARKct.

\section{REFERENCES}

1. Van Trigt P, Davis RD, Shaeffer GS, Gaynor JW, Landolfo KP, Higginbotham MB, et al. Survival benefits of heart and lung transplantation. Ann Surg 1996;223:576-84.

2. Tenderich G, Koerner MM, Stuettgen B, Minami K, El-Banayosy A, Arusoglu L, et al. Mechanical circulatory support after orthotopic heart transplantation. Int J Artif Organs 1998;21:414-6.

3. Bristow MR, Ginsburg R, Minobe W, Cubiciotti RS, Sageman WS, Lurie K, et al. Decreased catecholamine sensitivity and $\beta$ adrenergic density in failing human hearts. $\mathrm{N}$ Engl $\mathrm{J}$ Med 1982;307:205-11.

4. Lohse MJ, Engelhardt S, Danner S, Bohm M. Mechanisms of $\beta$ adrenergic receptor desensitization: from molecular biology to heart failure. Basic Res Cardiol 1996;91:29-34.

5. Cruz Caturla M, Masotti M, Brodde OE, Hjemdahl P, Velasquez $\mathrm{D}$, Tura A, et al. Development of myocardial $\beta$-adrenergic receptor density and adenylate cyclase activity after human heart transplantation. J Heart Lung Transplant 1992;11:1059-65.

6. Deniss AR, Marsh JD, Quigg RJ, Gordon JB, Colucci WS. Beta adrenergic receptor number and adenylate cyclase function in dennervated transplanted and cardiomyopathic human hearts. Circulation 1989;79:1028-34.

7. Hanna AK, Miller J, Liang BT, Disesa V. Reversible contractile dysfunction in reversible experimental cardiac allograft rejection: 
alterations in the $\beta$-receptor stimulated adenylyl cyclase pathway. J Surg Res 1993;54:610-5.

8. Yokoyama H, Ohmi M, Iguchi A, Murata S, Nakame T, Tabayashi K, et al. Changes in myocardial $\beta$-adrenergic receptors during acute rejection of heterotopically transplanted rat hearts. $\mathbf{J}$ Thorac Cardiovasc Surg 1992;104:1567-71.

9. Koch WJ, Hawes BE, Inglese J, Luttrell LM, Lefkowitz RJ. Cellular expression of the carboxyl terminus of a $\mathrm{G}$ protein-coupled receptor kinase attenuates G $\beta \gamma$-mediated signaling. J Biol Chem 1994;269:6193-7.

10. Koch WJ, Rockman HA, Samama P, Hamilton RA, Bond RA, Milano CA, et al. Cardiac function in mice overexpressing the $\beta$-adrenergic kinase or a $\beta A R K$ inhibitor. Science 1995; 268:1350-3.

11. Milano CA, Allen LF, Rockman HA, Dolber PC, McMinn TR, Chien KR, et al. Enhanced myocardial function in transgenic mice overexpressing the $\beta 2$-adrenergic receptor. Science 1994;264:582-6.

12. Koch WJ, Lefkowitz RJ, Rockman HA. Functional consequences of altering myocardial adrenergic receptor signaling. Annu Rev Physiol 2000;62:237-60.

13. Engelhardt S, Hein L, Wiesmann F, Lohse MJ. Progressive hypertrophy and heart failure in $\beta 1$-adrenergic receptor transgenic mice. Proc Natl Acad Sci U S A 1999;96:7059-64.

14. Akhter SA, Skaer CA, Kypson AP, McDondald PH, Peppel KC, Glower DD, et al. Restoration of $\beta$-adrenergic signaling in failing cardiac ventricular myocytes via adenoviral mediated gene transfer. Proc Natl Acad of Sci U S A 1997;94:12100-5.

15. Kypson AP, Peppel K, Akhter SA, Lilly E, Glower DD, Lefkowitz RJ, et al. Ex vivo adenovirus-mediated gene transfer to the transplanted adult rat heart. J Thorac Cardiovasc Surg 1998;115:623-30.

16. Kypson AP, Hendrickson SC, Akhter SA, Wilson K, McDonald $\mathrm{PH}$, Lilly RE, et al. Adenoviral mediated gene transfer of the $\beta 2$ adrenergic receptor to donor hearts enhances function. Gene Ther 1999;6:1298-304.

17. Brauner R, Wu L, Laks H, Nonoyama M, Scholl F, Shvarts, et al. Intracoronary gene transfer of immunosupressive cytokines to cardiac allografts: method and efficacy of adenovirus-mediated transduction. J Thorac Cardiovasc Surg 1997;113:1059-67.

18. Dalesandro J, Akimoto H, Gorman CM, McDonald TO, Thomas R, Liggitt HD, et al. Gene therapy for donor hearts: ex vivo liposome-mediated transfection. J Thorac Cardiovasc Surg 1996;111:416-21.
19. Brauner R, Nonoyama M, Laks H, Drinkwater DC, McCaffery S, Drake $\mathrm{T}$, et al. Intracoronary adenovirus-mediated transfer of immunosuppressive cytokine genes prolongs allograft survival. J Thorac Cardiovasc Surg 1997b;114:923-33.

20. Qin L, Ding Y, Bromberg JS. Gene transfer of transforming factor $\beta 1$ prolongs murine cardiac allograft survival by inhibiting cell mediated immunity. Hum Gene Ther 1996;7:1981-8.

21. Ono K, Lindsey ES. Improved technique of heart transplantation in rats. J Thorac Cardiovasc Surg 1969;57:225-9.

22. Langendorff O. Untersuchungen am uberlebenden Saugethierherzen. Arch Gen Physiol (Pfluger) 1895;61:291-332.

23. Bittner HB, Kendall SW, Chen EP, Davis RD, Van Trigt P III. Myocardial performance after graft preservation and subsequent cardiac transplantation from brain-dead donors. Ann Thorac Surg 1995;60:47-54.

24. Fyfe B, Loh E, Winters GL, Couper GS, Kartashov AI, Schoen FJ. Heart transplantation-associated perioperative ischemic myocardial injury: morphological features and clinical significance. Circulation 1996;93:1133-40.

25. Rockman HA, Chien KR, Choi D, Iaccarino G, Hunter JL, Ross J, Lefkowitz RJ, et al. Expression of a $\beta$-adrenergic receptor kinase 1 inhibitor prevents the development of myocardial failure in gene-targeted mice. Proc Natl Acad Sci U S A 1998;95:7000-5.

26. Choi D-J, Koch WJ, Hunter JJ, Rockman. Mechanism for $\beta$ adrenergic receptor desensitization in cardiac hypertrophy is increased $\beta$-adrenergic receptor kinase. J Biol Chem 1997;272:17223-9.

27. Ungerer M, Kessebohm K, Kronsbein K, Lohse MJ, Richardt G. Activation of $\beta$-adrenergic receptor kinase during myocardial ischemia. Circ Res 1996;79:455-60.

28. Ungerer M, Bohm M, Elce JS, Erdmann E, Lohse ML. Altered expression of $\beta$-adrenergic receptor kinase and $\beta 1$-adrenergic receptors in heart failure. Circulation 1993;87:454-63.

29. Gros R, Benovic JL, Tan M, Feldman RD. G protein-coupled receptor kinase activity is increased in hypertension. J Clin Invest 1997;99:2087-93.

30. Chester MR, Madden B, Barnett D, Yacoub M. The effect of orthotopic transplantation on total, $\beta 1$ and $\beta 2$-adrenoreceptors in the human heart. Br J Clin Pharmacol 1992;33:417-22.

31. Maurice J, Hata JA, Shah AS, White DC, Wilson KH, McDonald $\mathrm{PH}$, et al. Enhancement of cardiac function following adenoviralmediated in vivo intracoronary $\beta 2$-adrenergic receptor gene delivery. J Clin Invest 1999;104:21-9. 